\title{
Analisis Pengaruh Faktor Fundamental Dan Makro Ekonomi Terhadap Return Saham \\ (Studi Kasus Pada Indsutri Makanan Dan Minuman Yang Terdaftar Di Bursa Efek Indonesia Periode 2011-2015)
}

\author{
Chairul Aly Ramli \\ Email: chairulaly@aipnusra.ac.id
}

\begin{abstract}
The population of this research is Food and Beverage Sector Companies listed on the Indonesia Stock Exchange period 2011 - 2013 as many as 14 companies. Sampling technique used was purposive sampling and obtained a sample of 11 companies. Variables used in this study were, Stock Return as the dependent variable and the Current Ratio, Debt to Equity Ratio, Return On Asset, Total Assets Turnover, exchange rate, inflation and interest rates SBI as an independent variable. The analysis technique used is multiple linear regression analysis with a significance level of 0.05 . The results of regression analysis using partial test (t-test) showed that the variables Current Ratio, Debt to Equity Ratio, Return on Assets, Total Assets Turnover, exchange rate, inflation rates has no effect on stock returns of food and beverage sector. While the SBI rate have significant negative effect on stock return of food and beverage sector. From the results of the regression analysis of the results obtained simultaneously with a significance level of 0.05 (5\%) of independent variables influence on stock returns.
\end{abstract}

\section{Keywords : Stock Return, CR, DER, ROA, TATO, Exchange Rate, Interest Rates, Inflation}

\section{PENDAHULUAN}

Investasi merupakan penundaan konsumsi pada saat ini dengan tujuan untuk mendapatkan tingkat keuntungan atau pengembalian (return) yang akan diterima di masa yang akan datang. Return (kembalian) merupakan hal yang terpenting di dalam menentukan keputusan investasi. Menurut Ang (1997) ada dua faktor yang mempengaruhi return suatu investasi yaitu pertama, faktor internal perusahaan seperti kualitas dan reputasi manajemennya, struktur modal, struktur utang perusahaan dan sebagainya. Kedua adalah faktor eksternal, misalnya pengaruh kebijakan moneter dan fiskal, perkembangan sektor industrinya, faktor ekonomi misalnya terjadinya inflasi nilai tukar mata uang domestik terhadap mata uang asing, tingkat suku Bunga dan sebagainya.

Bagi para investor, mengetahui kondisi internal perusahaan merupakan hal yang penting. Informasi internal perusahaan bisa dilihat dari laporan keuangan perusahaan, dan digunakan untuk melakukan analisis fundamental. Dalam analisis fundamental perusahaan yang mempegaruhi return suatu investasi yaitu dengan menggunakan rasio keuangan, dimana dalam penelitian ini rasio likuiditas adalah dengan menggunakan Current ratio (CR) yang merupakan rasio perbandingan antara aktiva lancar dengan hutan lancar (Weston \& Copeland, 2010). Rasio solvabilitas dengan menggunakan Debt To Equity
Ratio (DER). Rasio solvabilitas sering dikaitkan dengan return saham yaitu Debt To Equity Ratio (DER) mencerminkan kemampuan perusahaan dalam memenuhi seluruh kewajibannya yang ditunjukkan oleh beberapa bagian dari modal sendiri yang digunakan untuk membayar hutang. Rasio profitabilitas dengan menggunakan Return On Asset (ROA). Return On Asset (ROA) digunakan untuk mengukur efektifitas perusahaan dalam menghasilkan keuntungan dengan memanfaatkan aktiva yang dimilikinya. Rasio aktivitas dengan menggunakan Total Asset Turn Over (TATO). TATO merupakan ukuran yang digunakan untuk menilai efisiensi manajemen dalam menjalankan perusahaan.

Kondisi ekonomi merupakan salah satu informasi teknikal. Ang (1997) menyatakan bahwa kondisi ekonomi merupakan dasar dari analisis sekuritas, dimana kondisi ekonomi memburuk, Tingkat suku bunga merupakan daya tarik bagi investor dalam menanamkan investasinya dalam bentuk deposito atau SBI sehingga investasi dalam bentuk saham akan tersaingi. Tingginya tingkat inflasi menunjukka bahwa risiko untuk melakukan investasi cukup besar sebab inflasi yang tinggi akan mengurangi tingkat pengembalian (rate of return) dari investasi. Fluktuasi nilai tukar suatu mata uang juga dapat mempengaruhi kegiatan dan nilai pasar atas pasar lokal. Jika perusahaan pada taraf internasional, hal ini berarti return saham perusahaan dipengaruhi oleh perubahan nilai tukar 
mata uang karena berdampak terhadap laporan perdagangan dan modal atas keseimbangan pembelian dalam negeri.

Dalam penelitian ini memfokuskan pada perusahaan makanan dan minuman, dimana perusahaan-perusahaan ini merupakan perusahaan yang menyediakan kebutuhan primer ataupun kebutuhan sekunder masyarakat. Sektor makanan dan minuman memegang peranan cukup penting dalam perkembangan industry nasional. Kondisi tersebut mengakibatkan sektor ini menjadi salah satu pilihan para investor sebagai sarana investasi yang menjanjikan. Hal ini ditandai dengan semakin banyaknya perusahaan makanan dan minuman yang go public dan menunjukkan bahwa perusahaan tersebut telah cukup besar usahanya dapat menyerap tenaga kerja dan investasi modal yang cukup besar.

Berikut merupakan data empiris tingkat pengembalian saham perusahaan makanan dan minuman yang terdaftar di Bursa Efek Indonesia periode 2011-2015.

Tabel 1.1. Return Saham Perusahaan Makanan Dan Minuman Periode 2011-2015

\begin{tabular}{|c|c|c|c|c|c|c|}
\hline \multirow{2}{*}{ Code } & \multirow{2}{*}{ Nama Emiten } & \multicolumn{5}{|c|}{ Return } \\
\hline & & 2011 & 2012 & 2013 & 2014 & 2015 \\
\hline AISA & Tiga Pilar Sejahtera Food Tbk & -0.025 & 0.080 & 0.027 & 0.036 & -0.041 \\
\hline CEKA & Cahaya Kalbar Tbk & -0.007 & 0.059 & -0.001 & 0.037 & -0.044 \\
\hline DLTA & Delta Djakarta Tbk & -0.005 & 0.076 & 0.035 & 0.004 & -0.122 \\
\hline ICBP & \begin{tabular}{|l} 
Indofood CBP Sukses Makmur Tbk \\
\end{tabular} & 0.011 & 0.039 & 0.024 & 0.023 & 0.005 \\
\hline INDF & Indofood Sukses Makmur Tbk & -0.001 & 0.021 & 0.013 & 0.002 & -0.019 \\
\hline MLBI & Multi Bintang Indonesia Tbk & 0.025 & 0.064 & 0.053 & -0.073 & -0.020 \\
\hline MYOR & Mayora Indah Tbk & 0.031 & 0.033 & 0.030 & -0.015 & 0.036 \\
\hline ROTI & Nippon Indosari Corporindo Tbk & 0.026 & 0.064 & -0.075 & 0.029 & -0.006 \\
\hline SKLT & \begin{tabular}{|l|} 
Sekar Laut Tbk \\
\end{tabular} & 0.000 & 0.024 & 0.000 & 0.094 & 0.018 \\
\hline STTP & \begin{tabular}{|l} 
Siantar Top Tbk \\
\end{tabular} & 0.054 & 0.059 & 0.038 & 0.060 & 0.004 \\
\hline ULTJ & $\begin{array}{l}\text { Ultrajaya Milk Industry and Trading } \\
\text { Company Tbk }\end{array}$ & 0.000 & 0.023 & 0.120 & -0.014 & 0.006 \\
\hline
\end{tabular}

Dari data di atas menunjukkan bahwa ada banyak faktor yang menyebabkan peningkatan dan penurunan tingkat return saham baik dari segi fundamental maupun makro ekonomi, sehingga penelitian ini ingin melakukan penelitian yang berjudul "Analisis Pengaruh Faktor Fundamental dan Makroekonomi terhadap Return Saham perusahaan Makanan dan Minuman (Studi pada Sektor Makanan dan Minuman yang terdaftar di BEI Periode 2011-2015).

\section{LANDASAN TEORI Return Saham}

Return saham adalah tingkat keuntungan yang dinikmati oleh pemodal atas suatu investasi yang dilakukan (Ang, 1997). Return sendiri merupakan hasil yang diperoleh dari investasi yang berupa return realisasi (realized return) dan return espektasi (Expected return).

\section{Aspek Fundamental}

Analisis fundamental merupakan analisis yang berhubungan dengan faktor fundamental perusahaan yang ditunjukkan dalam laporan keuangan perusahaan. Analisis fundamental merupakan analisis yang berhubungan dengan faktor fundamental perusahaan yang ditunjukkan dalam laporan keuangan perusahaan.

Analisi fundamental dengan menggunakan beberapa rasio, rasio keuangan dapat dikelompokkan dalam 5 jenis yaitu rasio likuiditas (liquiditas ratio), rasio aktivitas, rasio rentabilitas (profitabilitas ratio), rasio solvabilitas, dan rasio pasar (Ang, 1997). Dalam penelitian ini digunakan 4 rasio keuangan yang digunakan yaitu Current Ratio (CR) merupakan rasio likuiditas, Debt to Equity Ratio (DER) merupakan rasio solvabilitas, Return on Asset (ROA) merupakan rasio profitabilitas, dan Total Asset Turn Over (TATO) merupakan rasio aktivitas.

Aspek Makroekkonomi

Analisis makro ekonomi merupakan analisis terhadap faktor-faktor makro yang dapat mempengaruhi suatu perusahaan dan terjadi di luar perusahaan, sehingga hal tersebut tidak dapat dikendalikan oleh perusahaan. Makro ekonomi berfokus pada perilaku dan kebijakan ekonomi yang dapat mempengaruhi tingkat konsumsi dan investasi, neraca perdagangan dan pembayaran suatu Negara, faktor-faktor penting yang mempengaruhi harga dan upah, kebijakan fiskal moneter, jumlah uang yang beredar, tingkat suku bunga dan jumlah utang Negara (Donbusch, 2008). Secara teori, banyak terdapat indikator yang dapat mengukur variabel ekonomi, namun demikian dari sekian indikator yang lazim digunakan untuk memprediksi fluktuasi saham adalah variabel yang secara langsung dikendalikan melalui kebijakan moneter dengan mekanisme transmisi melalui pasar keuangan (Bank Indonesia, (2004) variabelvariabel tersebut meliputi nilai tukar rupiah, tingkat suku bunga, inflasi.

\section{Nilai Tukar Rupiah}

Pengertian nilai tukar menurut FASB adalah rasio antara suatu unit mata uang dengan sejumlah mata uang lain yang bisa ditukar pada waktu tertentu.

\section{Tingkat Suku Bunga}

Tingkat Suku Bunga atau intrest rate merupakan rasio pengembalian atas sejumlah investasi sebagai bentuk imbalan yang diberikan kepada investor (Husnan, 1995). Tingkat suku bunga sektor keuangan yang lazim digunakan sebagai panduan investor disebut juga tingkat suku bunga bebas risiko (risk free), yaitu yang meliputi tingkat suku bunga bank sentral dan tingkat suku bunga deposito. Di Indonesia tingkat suku bunga bank sentral diproksikan pada tingkat suku bunga 
Jurnal Ilmu Sosial dan Pendidikan

http://ejournal.mandalanursa.org/index.php/JISIP/index

Terakreditasi Peringkat 5 (No. SK: 85/M/KPT/2020)
Vol. 5. No. 2 Maret 2021

p-ISSN: 2598-9944 e-ISSN: 2656-6753
Sertifikat Bank Indonesia atau SBI (Husnan, 2009).

Inflasi

Menurut Herman (2003), inflasi adalah suatu keadaan yang ditandai dengan peningkatan harga-harga pada umumnya atau turunnya nilai mata uang yang beredar. Indikator inflasi sebagai berikut (www.bi.go.id). Tingkat inflasi yang tinggi juga bisa mengurangi tingkat pendapatan riil yang diperoleh investor dari investasinya. Sebaliknya jika tingkat investasi suatu Negara mengalami penurunan, maka hal ini merupakan sinyal positif bagi investor seiring dengan turunnya risiko daya beli uang dan risiko pendapatan riil (Tandelilin, 2003). Jadi inflasi yang tinggi menyebabkan menurunnya keuntungan suatu perusahaan, sehingga menyebabkan efek ekuitas menjadi kurang kompetitif (Ang, 1997).

\section{HIPOTESIS}

H1: CR berpengaruh positif terhadap return saham Perusahaan Sektor Industri Makanan Dan Minuman.

H2: DER berpengaruh negatif terhadap Return Saham Perusahaan Sektor Industri Makanan dan Minuman.

H3: ROA berpengaruh posotif terhadap return saham Perusahaan Sektor Industri Makanan dan Minuman

H5: Nilai tukar berpengaruh negatif terhadap return saham perusahaan sektor industry makanan dan minuman.

H6: Variabel tingkat suku Bunga SBI berpengaruh negatif terhadap return saham perusahaan Industri Makanan dan Minuman

H7: Variabel inflasi berpengaruh negatif terhadap return saham perusahaan Industri Makanan Dan Minuman

\section{METODE PENELITIAN \\ Populasi dan Sampel \\ Populasi}

Populasi dalam penelitian ini adalah perusahaan manufaktur sektor makanan dan minuman yang tercatat di Bursa Efek Indonesia dalam periode 2011-2015. Jumlah perusahaan pada industry makanan dan minuman yang terdaftar di BEI sampai tahun 2015 sebanyak 14 perusahaan. Sampel

Teknik pengambilan sampel dilakukan melalui metode purposive sampling dengan tujuan untuk mendapatkan sampel yang sesuai dengan tujuan penelitian. Menurut Sugiono (2010) metode purposive sampling adalah tehnik penentuan sampel dengan pertimbangan tertentu.
Tabel 3.1. Daftar Sampel Perusahaan Sektor Makanan Dan Minuman

\begin{tabular}{|l|l|}
\hline \multicolumn{1}{|c|}{ Code } & \multicolumn{2}{c|}{ Nama Emiten } \\
\hline AISA & Tiga Pilar Sejahtera Food Tbk \\
\hline CEKA & Cahaya Kalbar Tbk \\
\hline DLTA & Delta Djakarta Tbk \\
\hline ICBP & Indofood CBP Sukses Makmur Tbk \\
\hline INDF & Indofood Sukses Makmur Tbk \\
\hline MLBI & Multi Bintang Indonesia Tbk \\
\hline MYOR & Mayora Indah Tbk \\
\hline ROTI & Nippon Indosari Corporindo Tbk \\
\hline SKLT & Sekar Laut Tbk \\
\hline STTP & Siantar Top Tbk \\
\hline ULTJ & Ultrajaya Milk Industry and Trading Company Tbk \\
\hline
\end{tabular}

Sumber: data diolah

Definisi Operasional Variabel

Variabel Independen

Current Ratio (CR)

Rumus:

$$
\text { Current Ratio }=\frac{\text { Aktiva lancar }}{\text { Hutang Lancar }}
$$

Debt Equity Ratio (DER)

Rumus:

$$
\text { DER }=\frac{\text { Total Hutang }}{\text { Ekuitas Pemegang Saham }}
$$

Return On Asset (ROA)

Rumus:

$$
\begin{array}{r}
\text { Total Asset Turn Over }(\text { TATO) } \\
\text { TATO }=\frac{\text { Penjualan }}{\text { Total Aktiva }}
\end{array}
$$

$$
\mathrm{ROA}=\frac{\text { Laba } \text { bersih }}{\text { Total Aktiva }}
$$

\section{Nilai Tukar Rupiah}

Nilai tukar rupiah digunakan untuk mengukur kurs mata uang rupiah dalam satuan valuta asing (US\$). Harga rupiah dalam satuan US\$ dirumuskan dengan 1/R. data diambil melalui situs resmi BI dalam kurun waktu penelitian 20112015.

Tingkat Suku Bunga

Tingkat suku bunga diukur melalui tingkat suku bunga sertifikat Bank Indonesia selama periode 2011-2015.

Inflasi

Inflasi adalah kecendrungan dari hargaharga untuk menaik secara umum dan terus menerus. Untuk menghitung besarnya inflasi terlebih dahulu harus diketahui indeks harga konsumen (IHK).

Variabel Dependen saham.

Variabel dependen merupakan return

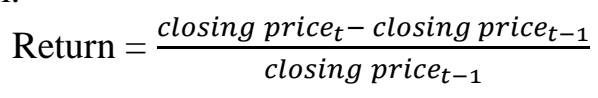


Jurnal Ilmu Sosial dan Pendidikan

http://ejournal.mandalanursa.org/index.php/JISIP/index

Terakreditasi Peringkat 5 (No. SK: 85/M/KPT/2020)

\section{Alat Analisis}

\section{Uji Asumsi Klasik}

Pengujian asumsi klasik yang digunakan dalam penelitian ini yaitu uji normalitas, uji multikolinieritas, heteroskidastisitas dan autokorelasi.

\section{Analisis Regresi Berganda}

Tehnik analisis yang akan dipakai dalam penelitian ini adalah dengan memakai tehnik analisis regresi linier berganda untuk memperoleh gambaran yang menyeluruh mengenai hubungan antara variabel satu dengan variabel yang lain.

Persamaan regresi:

$$
\begin{gathered}
\mathrm{Y}=\alpha+\beta_{1} X_{1}-\beta_{2} X_{2}+\beta_{3} X_{3}+\beta_{4} X_{4}+\beta_{5} X_{5}- \\
\beta_{6} X_{6}-\beta_{7} X_{7}+\mu_{i}
\end{gathered}
$$

\section{Uji F (Uji Simultan)}

Uji $F$ digunakan untuk menguji signifikasnsi pengaruh antara variabel bebas terhadap variabel terikat. Apabila nilai $F_{\text {hitung }}>$ $F_{\text {tabel }}$ maka Ho ditolak dan apabila $F_{\text {hitung }}<$ $F_{\text {tabel }}$ maka Ho d terima.

Uji t (Parsial)

Uji t digunakan untuk menguji pengaruh masing-masing antara variabel bebas terhadap variabel terikat.

Uji Determinasi $\left(R^{2}\right)$

Nilai $R^{2}$ yang semakin tinggi menjelaskan bahwaa variabel independen semakin baik kemampuannya dalam menjelaskan variabel dependen pada penelitian. Semakin kecil nilai $\mathrm{R}^{2}$ berarti semakin sedikit kemampuan variabelvariabel independen untuk menjelaskan variabel dependen pada penelitian.

\section{ANALISIS DATA DAN PEMBAHASAN \\ Uji Asumsi Klasik \\ Uji Normalitas}

Uji normalitas ini bertujuan untuk mengetahui distribusi data dalam variabel yang akan digunakan dalam penelitian.

Tabel 4.2. Hasil Uji Normalitas

\begin{tabular}{|l|l|r|}
\hline \multicolumn{2}{|c|}{} & \multicolumn{1}{|c|}{$\begin{array}{r}\text { Standardize } \\
\text { d Residual }\end{array}$} \\
\hline N & Mean & 55 \\
\hline \multirow{2}{*}{ Normal Parameters } & a,b & .0000000 \\
\cline { 2 - 3 } & $\begin{array}{l}\text { Std. } \\
\text { Deviation }\end{array}$ & .93293642 \\
\hline \multirow{2}{*}{$\begin{array}{l}\text { Most Extreme } \\
\text { Differences }\end{array}$} & Absolute & .089 \\
\cline { 2 - 3 } & Positive & .087 \\
\cline { 2 - 3 } & Negative & -.089 \\
\hline Test Statistic & & .089 \\
\hline Asymp. Sig. (2-tailed) & & $.200^{\mathrm{c}, \mathrm{d}}$ \\
\hline
\end{tabular}

Sumber: Data sekunder yang diolah

Berdasarkan hasil pengolahan data menunjukkan bahwa data berdistribusi normal. Hal ini ditunjukkan dengan nilai signifikansi 0,200 lebih besar dari 0,05 .
Vol. 5. No. 2 Maret 2021

p-ISSN: 2598-9944 e- ISSN: 2656-6753

\section{Uji Multikolinieritas}

Uji multikolinieritas bertujuan untuk menguji apakah pada model regresi ditemukan korelasi antara variabel-variabel bebas. uji multikolinieritas bertujuan untuk menguji apakah pada model regresi ditemukan korelasi antara variabel-variabel bebas.

Tabel 4.3. Hasil Uji Multikolinieritas

\begin{tabular}{|l|l|r|r|}
\hline \multirow{2}{*}{ Model } & \multicolumn{2}{|c|}{ Collinearity Statistic } \\
\cline { 2 - 4 } & \multicolumn{2}{|c|}{ Tolerance } & VIF \\
\hline \multirow{4}{*}{1} & (Constant) & & \\
\cline { 2 - 4 } & CR & 0.535 & 1.869 \\
\cline { 2 - 4 } & DER & 0.560 & 1.785 \\
\cline { 2 - 4 } & ROA & 0.849 & 1.178 \\
\hline \multirow{4}{*}{ TATO } & 0.815 & 1.227 \\
\hline SBI & 0.178 & 5.603 \\
\hline KURS & 0.178 & 5.615 \\
\hline & INFLASI & 0.925 & 1.081 \\
\hline
\end{tabular}

Sumber: Data Sekunder Yang Diolah

Berdasarkan tabel di atas menunjukkan bahwa semua variabel independen memiliki nilai tolerance berada di atas 0,10 dan VIF di bawah 10 . Hal ini menunjukkan dalam model ini tidak terjadi multikolinieritas artinya tidak ada korelasi antar variabel independen.

\section{Uji Autokorelasi}

Uji autokorelasi bertujuan untuk menguji apakah dalam model regresi linier ada korelasi antara kesalahan pengganggu pada periode $t$ dengan kesalahan periode t-1 (sebelumnya).

Tabel 4.4. Hasil Uji Autokorelasi

\begin{tabular}{|l|r|}
\hline & $\begin{array}{c}\text { Unstandardized } \\
\text { Residual }\end{array}$ \\
\hline Test Valuea & -0.00027 \\
\hline Cases < Test Value & 27 \\
\hline Cases >= Test Value & 28 \\
\hline Total Cases & 55 \\
\hline Number of Runs & 24 \\
\hline Z & -1.223 \\
\hline Asymp. Sig. (2-tailed) & 0.221 \\
\hline
\end{tabular}

Sumber: Data Sekunder Yang Diolah

Dari tabel di atas menunjukkan bahwa tidak terjadi autokorelasi dalam model regresi. Hal ini ditunjukkan nilai Asymp. Sig. (2-tailed) sebesar 0,221 lebih besar dari 0,05. Dengan demikian, data yang dipergunakan random (acak) sehingga tidak terjadi masalah autokorelasi pada data yang diuji.

\section{Uji Heteroskedastisitas}

Heteroskedastisitas bertujuan untuk menguji apakah model regresi terjadi ketidak 
samaan varian dari residual satu pengamatan ke pengamatan yang lain.

Tabel 4.5. Uji Heteroskedastisitas

\begin{tabular}{|l|l|l|l|l|l|l|}
\hline \multirow{2}{*}{} & \multicolumn{2}{|l|}{$\begin{array}{l}\text { Unstandardized } \\
\text { Coefficients }\end{array}$} & $\begin{array}{l}\text { Standardized } \\
\text { Coefficients }\end{array}$ & \multirow{2}{*}{ Sig. } \\
\cline { 2 - 5 } & B & $\begin{array}{l}\text { Std. } \\
\text { Error }\end{array}$ & Beta & & \\
\hline \multirow{2}{*}{1} & (Constant) & 0.073 & 0.118 & & 0.614 & 0.542 \\
\cline { 2 - 6 } & CR & 0.004 & 0.003 & 0.201 & 1.062 & 0.293 \\
\hline DER & 0.012 & 0.008 & 0.288 & 1.555 & 0.127 \\
\hline ROA & -0.032 & 0.029 & -0.167 & -1.109 & 0.273 \\
\hline TATO & 0.004 & 0.007 & 0.097 & 0.63 & 0.532 \\
\hline Suku Bunga & -0.773 & 1.144 & -0.221 & -0.675 & 0.503 \\
\hline $\begin{array}{l}\text { Nilai tukar } \\
\text { Rupiah }\end{array}$ & -2.565 & 4.577 & -0.184 & -0.56 & 0.578 \\
\cline { 2 - 5 } INFLASI & 0.14 & 0.145 & 0.139 & 0.966 & 0.339 \\
\hline
\end{tabular}

Sumber: Data Sekunder Yang Diolah

Tabel di atas menunjukkan bahwa tidak ada variabel independen (CR, DER, ROA, TATO, Suku Bunga, Nilai Tukar, Inflasi) yang signifikansi dengan variabel residual. Hal ini ditunjukkan dengan nilai signifikansi lebih besar dari 0,05. Hasil siignifikasin CR sebesar 0,293, DER sebesar 0,127 , ROA sebesar 0,273, TATO sebesar 0,532, Suku Bunga sebesar 0,503, Nilai Tukar Rupiah sebesar 0,578, Inflasi sebesar 0,339. Dengan demikian, dapat disimpulkan bahwa semua variabel independen tidak terjadi heteroskedastisitas.

\section{Analisis Regresi Berganda}

Bentuk model regresi yang digunakan dalam penelitian ini untuk mengetahui pengaruh variabel independen yaitu CR, DER, ROA TATO, Suku Bunga, Nilai Tukar, Inflasi terhadap Return Saham.

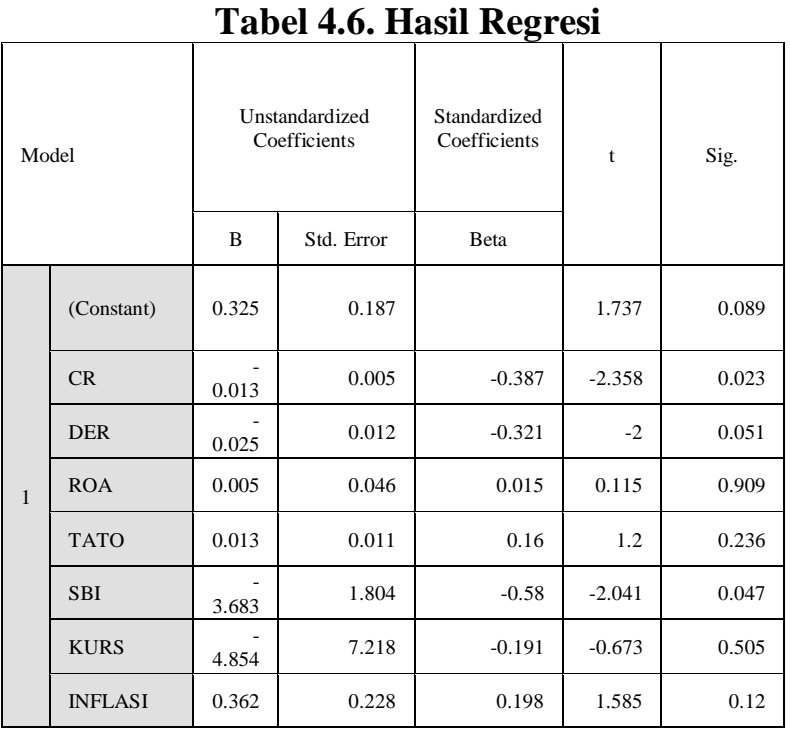

Sumber: Data Sekunder Yang Diolah

Berdasarkan tabel 4.5 diperoleh persamaan regresi sebagai berikut:

Return saham $=0,325-0,013 \mathrm{CR}-0,025 \mathrm{DER}+$ $0,005 \mathrm{ROA}+0,013 \mathrm{TATO}-3,683 \mathrm{SBI}-4,854 \mathrm{Kurs}$ $+0,362$ Inflasi
Uji T

a. Variabel CR memiliki nilai signifikansi 0,023, dimana nilai signifikansi lebih kecil dari pada 0,05 (5\%). Hal ini menunjukkan bahwa variabel $\mathrm{CR}$ berpengaruh secara signifikan terahadap return saham. Selain itu, variabel CR memiliki nilai koefisien (B) sebesar -0,013 artinya bahwa $\mathrm{CR}$ berpengaruh negative terhadap return saham perusahaan sektor makanan dan minuman.

Current ratio yang rendah menunjukkan terjadinya masalah likuiditas dan dapat diartikan sebagai indikator awal mengenai ketidak mampuan perusahaan untuk memenuhi kewajiban jangka pendeknya. Perusahaan dengan current ratio yang tinggi menunjukkan bahwa perusahaan tersebut mampu untuk memenuhi kewajiban jangka pendeknya. Namun current ratio yang tinggi juga menunjukkan bahwa kurang mampu mengelola money to create money, yang pada akhirnya dapat mengurangi kemampuan perusahaan untuk memperoleh laba berkurang. Hal ini akan berdampak pada menurunnya return saham.

b. Variabel DER memiliki nilai signifikansi 0,051, dimana nilai signifikasi tersebut lebih besar dari pada $0,050 \quad(5 \%)$. Hal ini menunjukkan bahwa variabel DER tidak berpengaruh signifikan terhadap return saham perusahaan sektor makanan dan minuman. Tidak adanya pengaruh signifikan dari DER terhadap return saham dapat berarti bahwa adanya penilaian yang berbeda dari investor terhadap artinya pentingnya hutang bagi perusahaan. Beberapa investor dapat berpikir bahwa DER yang tinggi akan menjadi beban bagi perusahaan, hal ini dikarenakan adanya kewajiban yang harus dibayar oleh perusahaan dan adanya risiko kebangkrutan yang akan ditanggung oleh investor. disisi lain beberapa investor juga berpendapat bahwa bahwa hutang diperlukan oleh perusahaan untuk menambah modal perusahaan, karena dengan menggunakan hutang, perusahaan dapat menggunakannya untuk menambah modal perusahaan

c. Variabel ROA memiliki nilai signifikansi sebesar 0,909, dimana nilai ini lebih besar dari 0,05 (5\%). Hal ini menunjukkan bahwa variabel ROA tidak berpengaruh signifikan terhadap return saham perusahaan sektor makanan dan minuman. ROA tidak berpengaruh terhadap return saham, hal ini disebabkan karena adanya variasi data 
penelitian. Hal ini dapat kita lihat dari hasil penelitian seperti yang terjadi pada tahun 2011 MLBI memiliki ROA tinggi sebesar 0,416 dengan return saham sebesar 0,025 sedangkan STTP yang memiliki ROA lebih rendah sebesar 0,046 memiliki return yang labiih tinggi sebesar 0,054. Pada tahun 2012 MLBI yang memiliki ROA yang tinggi yaitu sebesar 0,394 dengan return sebesar 0,064, sedangkan AISA yang memiliki ROA yang lebih rendah dari MLBI yaitu sebesar 0,066 memiliki return yang lebih tinggi sebesar 0,080. Pada tahun 2013 MLBI yang memiliki ROA tertinggi sebesar 0,657 tetapi return sahamnya rendah sebesar 0,053 sedangkan ULTJ yang memiliki ROA lebih rendah sebesar 0,116 dengan tingkat return saham yang lebih tinggi sebesar 0,120. Pada tahun 2014 MLBI memiliki ROA yang tinggi yaitu sebesar 0.356 dengan return saham sebesar -0.073, sedangkan CEKA yang memiliki ROA terendah yaitu sebesar 0,032 dengan return saham yang lebih tinggi sebesar 0,037. Pada tahun 2015 MLBI memiliki nilai ROA tertinggi yaitu sebesaar 0.237 dengan return saham sebesar -0,020, sedangkan SKLT yang memiliki ROA lebih rendah yaitu sebesar 0,053 dengan tinggikat return saham yang lebih tinggi yaitu sebesar 0,018 .

d. Variabel TATO memiliki nilai signifikansi sebesar 0,236, dimana nilai ini lebih besar dari $0,05(5 \%)$ hal ini menunjukkan bahwa variabel TATO tidak berpengaruh signifikan terhadap return saham perusahaan sektor makanan dan minuman. Kemampuan perusahaan dalam mengoptimalkan aktivanya secara efektif dan efisien ternyata tidak berpengaruh terhadap minat investor untuk membeli saham perusahaan tersebut, hal ini dapat terjadi karena beberapa perusahaan yang mampu menghasilkan TATO yang tinggi pada periode yang sama tidak diikuti laba yang labih besar yang membuat investor tidak tertarik untuk membeli saham perusahaan tersebut, sehingga menyebabkan harga saham perusahaan menurun yang berakibat terhadap turunnya return saham.

e. Variabel suku Bunga memilliki nilai signifikansi sebesar 0,047 , dimana nilai ini lebih kecil dari 0,05. Hal ini menunjukkan bahwa variabel suku bunga berpengaruh signifikan terhadap return saham perusahaan makanan dan minuman. Selain itu variabel suku bunga memiliki nilai koefisien (B) sebesar $-3,683$, artinya bahwa variabel suku bunga berpengaruh negative terhadap return saham perusahaan makanan dan minuman. Hal ini menjelaskan bahwa besarnya nilai suku bunga perusahaan mampu memberikan kontribusi yang signifikan dalam mempengaruhi tingkat return saham perusahaan. Jika nilai suku bunga turun akan menyebabkan laba yang dihasilkan dari seluruh kekayaan akan meningkat. Nilai koefisien regresi $(-3,683)$ menunjukkan arah hubungan kedua variabel tersebut negative. Return saham sensitif terhadap suku bunga dengan arah negatif yang menunjukkan perubahan return saham akan meningkat jika suku bunga rendah yang akan menyebabkan biaya modal lebih rendah. Suku bunga yang rendah akan merangsang investasi yang akan menyebabkan meningkatnya harga saham, dan akan berdampak pada peningkatan return saham.

f. Variabel nilai tukar rupiah memiliki nilai signifikansi sebesar 0,505 , dimana nilai ini lebih besar dari pada 0,05 (5\%). Hal ini menunjukkan bahwa variabel nilai tukar rupiah tidak berpengaruh signifikan terhadap return saham perusahaan makanan dan minuman. Kurs rupiah tidak mempunyai pengaruh terhadap return saham, hal ini disebabkan perusahaan makanan dan minuman tidak bergantung pada produk-produk atau bahan dari luar negeri. Sehingga adanya fluktuasi nilai tukar tidak akan berdampak signifikan terhadap return saham.

g. Variabel inflasi memiliki nilai signifikansi sebesar 0,12, dimana nilai ini lebih besar dari pada $0,05(5 \%)$. Hal ini menunjukkan bahwa variabel inflasi tidak berpengaruh signifikan terhadap return saham perusahaan makanan dan minuman. Sektor makanan dan minuman merupakan sektor yang bersifat defensive dengan barang-barang yang dibutuhkan oleh setiap orang. Selain itu juga tingkat inflasi yang terjadi masih relative stabil dan masih dapat mendorong perekonomian yang lebih baik. Kondisi inflasi yang masih relative stabil membuat para investor tidak memperhatikan tingkat inflasi dalam mempertimbangkan penjualan atau pembelian terhadap saham sektor makanan dan minuman.

\section{Uji F}

Tabel 4.7. Uji F

\begin{tabular}{|c|r|r|r|r|c|c|}
\hline \multicolumn{2}{|l|}{ Model } & $\begin{array}{c}\text { Sum of } \\
\text { Squares }\end{array}$ & df & $\begin{array}{c}\text { Mean } \\
\text { Square }\end{array}$ & F & Sig. \\
\hline 1 & Regression & 0.03 & 7 & 0.004 & 3.186 & $.008^{\mathrm{b}}$ \\
\hline
\end{tabular}




\begin{tabular}{|l|l|l|l|l|l|} 
Residual & 0.063 & 47 & 0.001 & & \\
\hline Total & 0.093 & 54 & & & \\
\hline
\end{tabular}

Sumber: Data Sekunder Yang Diolah

Dari tabel di atas menunjukkan bahwa secara bersama-sama variabel independen berpengaruh signifikan terhadap variabel dependen. Hal ini dapat dibuktikan dengan nilai signifikansi sebesar 0,008 lebih kecil dari 0,05 (5\%), maka dapat dikatakan bahwa perubahan Current Ratio (CR), Debt Equity Ratio (DER), Return On Asset (ROA), Total Asset Turn Over (TATO), Suku Bunga, Nilai Tukar, Inflasi secara bersama-sama berpengaruh terhadap return saham. Uji Determinasi $\left(\mathbf{R}^{2}\right)$

Koefisien determinasi (adjusted $R^{2}$ ) digunakan untuk mengukur seberapa jauh kemampuan model dalam menerangkan variabel dependennya.

Tabel 4.8. Uji Koefisien Determinasi

\begin{tabular}{|l|r|r|r|r|}
\hline Model & $\mathrm{R}$ & $\mathrm{R}$ Square & $\begin{array}{c}\text { Adjusted R } \\
\text { Square }\end{array}$ & $\begin{array}{r}\text { Std. Error of } \\
\text { the Estimate }\end{array}$ \\
\hline 1 & $.567^{\mathrm{a}}$ & 0.322 & 0.221 & 0.03671 \\
\hline
\end{tabular}

Sumber: Data Sekunder Diolah

Berdasarkan tabel 4.6 menunjukkan bahwa nilai koefisien determinasi $\left(\mathrm{R}^{2}\right)$ sebesar 0,221 atau $22,1 \%$. Hal ini menunjukkan bahwa besarnya pengaruh variabel independen yaitu perubahan CR, DER, ROA, TATO, Suku Bunga BI, Nilai Tukar, Inflasi terhadap variabel independen yaitu return saham yang diterangkan dalam model persamaan ini adalah $22,1 \%$ dan sisanya sebesasr $77,9 \%$ dipengaruhi oleh faktor lain yang tidak dimasukkan dalam penelitian ini

\section{KESIMPULAN}

Berdasarkan hasil pengujian dan pembahasan yang telah dilakukan, dapat ditarik kesimpulan:

Current ratio (CR) berpengaruh negatif terhadap return saham Perusahaan Makanan dan Minuman yang terdaftar di BEI periode 20112015. current ratio yang terlalu tinggi menunjukkan bahwa perusahaan kurang mampu mengelola money to create money, yang pada akhirnya dapat mengurangi kemampuan perusahaan untuk memperoleh laba berkurang. Hal ini akan berdampak pada menurunnya return saham.

Debt to equity ratio (DER) tidak berpengaruh terhadap return saham Perusahaan Makanan dan Minuman yang terdaftar di BEI periode 2011-2015. Keputusah untuk menambah hutang tidak selalu berdampak negatif. Ketika perusahaan menambah hutang tentunya dengan mempertimbangkan dampak yang diakibatkan. Selama manfaat masih masih lebih besar dari pada hutang, maka hutang masih bias ditambah, apabila terjadi sebaliknya kebijakan menambah hutang lebih baik tidak dilakukan.

Return on asset (ROA) tidak berpengaruh terhadap return saham Perusahaan Makanan dan Minuman yang terdaftar di BEI periode 20112015. Perusahaan kurang efektif dalam memanfaatkan aktivanya untuk menghasilkan keuntungan sehingga mengurangi daya Tarik investor untuk menanmkan dananya dalam perusahaan, hal ini akan berdampak pada return saham.

Total asset turn over (TATO) tidak berpengaruh terhadap return Perusahaan Makanan dan Minuman yang terdaftar di BEI periode 20112015. Hal ini dapat terjadi karena beberapa perusahaan yang mampu menghasilkan TATO yang tinggi pada periode yang sama tidak diikuti laba yang labih besar yang membuat investor tidak tertarik untuk membeli saham perusahaan tersebut, sehingga menyebabkan harga saham perusahaan menurun yang berakibat terhadap turunnya return saham. Total asset turn over (TATO) tidak berpengaruh terhadap return Perusahaan Makanan dan Minuman yang terdaftar di BEI periode 20112015. Hal ini dapat terjadi karena beberapa perusahaan yang mampu menghasilkan TATO yang tinggi pada periode yang sama tidak diikuti laba yang labih besar yang membuat investor tidak tertarik untuk membeli saham perusahaan tersebut, sehingga menyebabkan harga saham perusahaan menurun yang berakibat terhadap turunnya return saham.

Tingkat suku bunga SBI terbukti berpengaruh negative terhadap return saham Perusahaan Makanan dan Minuman yang terdaftar di BEI periode 2011-2015. Return saham sensitif terhadap suku bunga dengan arah negatif yang menunjukkan perubahn return saham akan meningkat jika suku bunga rendah yang akan menyebabkan biaya modal lebih rendah. Suku bunga yang rendah akan merangsang investasi yang akan menyebabkan meningkatnya harga saham, dan akan berdampak pada peningkatan return saham.

Nilai tukar rupiah tidak berpengaruh terhadap return saham Perusahaan Makanan dan minuman yang terdaftar di BEI periode 2011-2015. Hal ini dikarenakan ketika rupiah menguat terhadap mata uang asing (dollar), para investor justru lebih memilih berinvestasi pada valuta asing. Investasi pada saham menjadi tidak menarik lagi, 
sehingga hal ini mengakibatkan return saham menurun.

Inflasi tidak berpengaruh terhadap return saham Perusahaan Makanan dan Minuman yang terdaftar di BEI periode tahun 2011-2015. Ini disebabkan karena sektor makanan dan minuman merupakan sektor yang bersifat defensive dengan barang-barang yang dibutuhkan oleh setiap orang. Selain itu juga tingkat inflasi yang terjadi masih relative stabil dan masih dapat mendorong perekonomian yang lebih baik. Sehingga investor tidak memperhatikan faktor inflasi.

Hasil analisis dengan menggunakan uji $\mathrm{F}$ dalam penelitian ini menunjukkan bahwa $\mathrm{CR}$, DER, ROA, TATO, Suku Bunga SBI, Nilai Tukar Rupiah, Inflasi berpengaruh terhadap return saham pada perusahaan sektor Makanan dan Minuman di BEI periode 2011-2015. Hasil tersebut dibuktikan dengan nilai signifikansi sebesar 0,008 yang lebih kecil dari 0,05 . Nilai adjusted $R$ Square sebesar 0,221 atau $22,1 \%$, menunjukkan bahwa perubahan yang terjadi pada return saham dapat dijelaskan oleh CR, DER, ROA, TATO, Suku Bunga SBI, Nilai Tukar Rupiah, Inflasi sebesar 22,1 \% dan sisanya $77,9 \%$ dijelaskan oleh variabel lain.

\section{SARAN}

Investor dalam melakukan investasi pada saham perusahaan Makanan dan Minuman hendaknya memperhatikan variabel current ratio (CR). Nilai CR yang terlalu tinggi akan menyebabkan turunnya return saham. Hal ini dikarenakan perusahaan tidak memanfaat aktiva lancarnya secara efisien.

Faktor lain yang perlu diperhatikan investor dalam melakukan investasi di Bursa Efek yaitu tingkat suku bunga SBI, karena tingkat suku bunga yang semakin tinggi akan berakibat turunnya return saham

\section{DAFTAR PUSTAKA}

Ang, Robert, 1997, Buku Pintar: Pasar Modal Indonesia. Mediasoft Indonesia, Jakarta.

Arta, Denika Reka, DKK. (2014). Analisis Fundamental, Teknikal Dan Makroekonomi Harga Saham Sektor Pertanian. JMK. 16 (2). 175-184.

Arta, Denika Reka, DKK. (2014). Analisis Fundamental, Teknikal Dan Makroekonomi Harga Saham Sektor Pertanian. JMK. 16 (2). 175-184.

Asmi, Tri Laksita. 2013. Current Ratio, Debt To Equity Ratio, Total Asset Turnover, Return On Asset, Price To Book Value Sebagai Faktor Penentu Return Saham.
Management Analysis Journal. Vol. 3 (2).

Asmi, Tri Laksita. 2013. Current Ratio, Debt To Equity Ratio, Total Asset Turnover, Return On Asset, Price To Book Value Sebagai Faktor Penentu Return Saham. Management Analysis Journal. Vol. 3 (2).

Asri, I gusti Ayu A.Y. dan I Ketut Suwarta. (2014). Pengaruh Faktor Fundamental Dan Ekonomi Makro Terhadap Return Saham Pada Perusahaan Consumer Good. EJurnal Akuntansi Universitas Udayana. 8(3). 353-370.

Asri, I gusti Ayu A.Y. dan I Ketut Suwarta. (2014). Pengaruh Faktor Fundamental Dan Ekonomi Makro Terhadap Return Saham Pada Perusahaan Consumer Good. EJurnal Akuntansi Universitas Udayana. 8(3). 353-370.

Boediono. (2001). Ekonomi Moneter. Yogyakarta: BPFE.

Boediono. (2001). Ekonomi Moneter. Yogyakarta: BPFE.

Brigham, Eugene dan Houston Joel. (2006). Fundamentals of Financial Management. Terjemahan oleh Ali Akbar Y. Jakarta: Salemba Empat.

Brigham, Eugene dan Houston Joel. (2006). Fundamentals of Financial Management. Terjemahan oleh Ali Akbar Y. Jakarta: Salemba Empat.

Clude et. Al. 1996. Political Risk, Economic Risk, and Financial Risk. Financial Analysts Journal. November-Desember.

Clude et. Al. 1996. Political Risk, Economic Risk, and Financial Risk. Financial Analysts Journal. November-Desember.

Donbusch, et. al. 1980. Macroeconomic. Mc Graw-Hill companies, New York Roy Indra Mirazudin (Penerjemah). 2008. Makroekonomi, Edisi Kesepuluh Media Global Edukasi. Jakarta.

Donbusch, et. al. 1980. Macroeconomic. Mc Graw-Hill companies, New York Roy Indra Mirazudin (Penerjemah). 2008. Makroekonomi, Edisi Kesepuluh Media Global Edukasi. Jakarta.

Faoriko, Akbar. 2013. Pengaruh Inflasi, Suku Bunga, Dan Nilai Tukar Rupiah Terhadap Return Saham D Bursa Efek Indonesia. Skripsi Yang Diterbitkan $U N Y$. 
Faoriko, Akbar. 2013. Pengaruh Inflasi, Suku Bunga, Dan Nilai Tukar Rupiah Terhadap Return Saham D Bursa Efek Indonesia. Skripsi Yang Diterbitkan UNY.

Faried, Asbi Rahman. 2008. Analisis Pengaruh Faktor Fundamental dan Nilai Kapitalisasi Pasar Terhadap Return Saham Perusahaan Manufaktur di BEI Periode 2002-2006. Pascasarjana Universitas Diponegoro, Semarang.

Faried, Asbi Rahman. 2008. Analisis Pengaruh Faktor Fundamental dan Nilai Kapitalisasi Pasar Terhadap Return Saham Perusahaan Manufaktur di BEI Periode 2002-2006. Pascasarjana Universitas Diponegoro, Semarang.

Ghozali, Imam. 2006. Aplikasi Analisis Multivariate Dengan SPSS. Universitas Diponegoro, Semarang.

Ghozali, Imam. 2006. Aplikasi Analisis Multivariate Dengan SPSS. Universitas Diponegoro, Semarang.

Hanafi, Mamduh M., 2005, Manajemen Keuangan, BPFE, Yogyakarta.

Hanafi, Mamduh M., 2005, Manajemen Keuangan, BPFE, Yogyakarta.

Hardiningsih, Pancawati. 2002, "Pengaruh Faktor Fundamental Dan Resiko Ekonomi Terhadap Return Saham Pada Perusahaan Di Bursa Efek Jakarta: Studi Kasus Basic Industry \& Chemical". Jurnal Strategi Bisnis. Vol. 8, Des.

Hardiningsih, Pancawati. 2002, "Pengaruh Faktor Fundamental Dan Resiko Ekonomi Terhadap Return Saham Pada Perusahaan Di Bursa Efek Jakarta: Studi Kasus Basic Industry \& Chemical". Jurnal Strategi Bisnis. Vol. 8, Des.

Hasanah, Nur Aida. 2013. Pengaruh Likuiitas Terhadap Return Saham Pada Perusahaan Yang Terdaftar Di Jakarta Islamic Index. Skripsi Universitas Pendidikan Ekonomi dan Bisnis. Bandung.

Hasanah, Nur Aida. 2013. Pengaruh Likuiitas Terhadap Return Saham Pada Perusahaan Yang Terdaftar Di Jakarta Islamic Index. Skripsi Universitas Pendidikan Ekonomi dan Bisnis. Bandung.

Hayat, Wahid Al. 2014. Pengaruh Rasio Keuangan Terhadap Return Saham (Studi Empiris Pada Perusahaan Sektor Pertambangan Yang Terdaftar Di Bursa Efek Indonesia
Periode 2008-2013). Di Publikasikas oleh Universitas Muhammadiyah Surakarta.

Hayat, Wahid Al. 2014. Pengaruh Rasio Keuangan Terhadap Return Saham (Studi Empiris Pada Perusahaan Sektor Pertambangan Yang Terdaftar Di Bursa Efek Indonesia Periode 2008-2013). Di Publikasikas oleh Universitas Muhammadiyah Surakarta.

Herman, Budi Sasono, 2003, "Pengaruh Perbedaan Laju Inflasi dan Suku Bunga pada Nilai Tukar Rupiah terhadap Dollar Amerika, dalam Kurun Waktu Januari 2000-Desember 2002". Majalah Ekonomi, Th. XIII, No. 3, Desember.

Herman, Budi Sasono, 2003, "Pengaruh Perbedaan Laju Inflasi dan Suku Bunga pada Nilai Tukar Rupiah terhadap Dollar Amerika, dalam Kurun Waktu Januari 2000-Desember 2002”. Majalah Ekonomi, Th. XIII, No. 3, Desember.

Husnan, Suad. (2009). Teori Portofolio dan Analisis Sekuritas. Edisi Keempat. Yogyakarta: STIM YKPN.

Husnan, Suad. (2009). Teori Portofolio dan Analisis Sekuritas. Edisi Keempat. Yogyakarta: STIM YKPN.

Indriantoro, Nur., Supomo, Bambang. 1999. Metodologi Penelitian Bisnis, Untuk Akuntansi dan Manajemen, Edisi Pertama. BPFE, Yogyakarta.

Indriantoro, Nur., Supomo, Bambang. 1999. Metodologi Penelitian Bisnis, Untuk Akuntansi dan Manajemen, Edisi Pertama. BPFE, Yogyakarta.

Izedonmi, P. F. dan Ibrahim Bello Abdullahi. (2011). The Effects of Macroeconomic Factors on the Nigerian Stock Returns: A Sektoral Approach. Global Journals Inc. (USA). 11 (7).

Izedonmi, P. F. dan Ibrahim Bello Abdullahi. (2011). The Effects of Macroeconomic Factors on the Nigerian Stock Returns: A Sektoral Approach. Global Journals Inc. (USA). 11 (7).

Jogiyant o, HM, 1998, Teori Portofolio dan Analisis Investasi, Edisi Pertama, BPFE UGM, Yogyakarta.

Jogiyanto, HM, 1998, Teori Portofolio dan Analisis Investasi, Edisi Pertama, BPFE UGM, Yogyakarta.

Kretarto, Agus. 2001. Investor Relations, Pemasaran \& Komunikasi Keuangan 
Perusahaan Berbasis Kepatuhan. PT. Grafiti Pers, Jakarta.

Kretarto, Agus. 2001. Investor Relations, Pemasaran \& Komunikasi Keuangan Perusahaan Berbasis Kepatuhan. PT. Grafiti Pers, Jakarta.

Kriswanto. 2014. Pengaruh Faktor Fundamental Dan Ekonomimakro Terhadap Return Saham Syariah Di Jakarta Islamic Index (JII) Periode 2010-2013. Dipublikasikan Oleh Universitas Negeri Yogyakarta.

Kriswanto. 2014. Pengaruh Faktor Fundamental Dan Ekonomimakro Terhadap Return Saham Syariah Di Jakarta Islamic Index (JII) Periode 2010-2013. Dipublikasikan Oleh Universitas Negeri Yogyakarta.

Kuwarnu, J. K.M. Effect Of Macroeconomic Variable On The Ghanaian Stock Market Return: A Co-Integration Analysis. Economic and Informatics. IV (2).

Kuwarnu, J. K.M. Effect Of Macroeconomic Variable On The Ghanaian Stock Market Return: A Co-Integration Analysis. Economic and Informatics. IV (2).

Laili, Sasmita Nurvida. 2014. Analisis Faktor Fundamental dan Makroekonomi Terhadap Return Saham (Studi Pada Industri Media Advertising dan Pinting Di BEI Periode 2008-2013). Skripsi UIN Maulana Malik Ibrahim Malang.

Laili, Sasmita Nurvida. 2014. Analisis Faktor Fundamental dan Makroekonomi Terhadap Return Saham (Studi Pada Industri Media Advertising dan Pinting Di BEI Periode 2008-2013). Skripsi UIN Maulana Malik Ibrahim Malang.

Lani, Salim. 2003. Analisis Teknikal dalam Perdagangan Saham. PT Elex Media Komputindo Gramedia. Jakarta.

Lani, Salim. 2003. Analisis Teknikal dalam Perdagangan Saham. PT Elex Media Komputindo Gramedia. Jakarta.

Nazwar, Chairul. (2008). Analisis Pengaruh Variabel Makro Ekonomi Terhadap Return Saham Syariah di Indonesia. Jurnal Perencanaan dan Pengembangan wilayah. Vol 4, No. 1. Fakultas Ekonomi USU.

Nazwar, Chairul. (2008). Analisis Pengaruh Variabel Makro Ekonomi Terhadap Return Saham Syariah di Indonesia. Jurnal Perencanaan dan Pengembangan wilayah. Vol 4, No. 1. Fakultas Ekonomi USU.
Nidianti, Putu Imba. 2013. Pengaruh Faktor Internal Dan Eksternal Perusahaan Terhadap Return Saham Food And Beverages Di Bursa Efek Indonesia. EJurnal Akuntansi Universitas Udayana. Vol. 5 (1): 130-146.

Nidianti, Putu Imba. 2013. Pengaruh Faktor Internal Dan Eksternal Perusahaan Terhadap Return Saham Food And Beverages Di Bursa Efek Indonesia. EJurnal Akuntansi Universitas Udayana. Vol. 5 (1): 130-146.

Novitasari, Ryan. 2013. Analisis Pengaruh Variabel Fundamental Dan Makroekonomi Terhadap Return Saham (Pada Perusahaan LQ 45 Yang Terdaftar Di Bursa Efek Indonesia Tahun 20092012). Skripsi Universitas Diponegoro Semarang.

Novitasari, Ryan. 2013. Analisis Pengaruh Variabel Fundamental Dan Makroekonomi Terhadap Return Saham (Pada Perusahaan LQ 45 Yang Terdaftar Di Bursa Efek Indonesia Tahun 20092012). Skripsi Universitas Diponegoro Semarang.

Nugroho, Bramantyo, Daljono. 2013. Pengaruh Kinerja Keuangan Terhadap Return Saham (Studi Pada Perusahaan Automotive and Component) Yang Listing Di Bursa Efek Indonesia periode 2005-2011). Diponegoro Journal Of Accounting. Vol 2 (1): 1-11.

Nugroho, Bramantyo, Daljono. 2013. Pengaruh Kinerja Keuangan Terhadap Return Saham (Studi Pada Perusahaan Automotive and Component) Yang Listing Di Bursa Efek Indonesia periode 2005-2011). Diponegoro Journal Of Accounting. Vol 2 (1): 1-11.

Nuryana, Ida. (2013). Pengaruh Rasio Keuangan Terhadap Return Saham Perusahaan LQ-45 Di Bursa Efek Jakarta.

Nuryana, Ida. (2013). Pengaruh Rasio Keuangan Terhadap Return Saham Perusahaan LQ-45 Di Bursa Efek Jakarta.

Prihantini, Ratna. (2009). Analisis pengaruh Inflasi, Nilai Tukar, ROA, DER, dan CR terhadap Return Saham (Sutudi Kasus Saham Industri dan real Estate and Property yang Terdaftar di BEI Periode 2003-2006). Tesis yang diterbitkan. Semarang: Universitas Diponegoro. 
Prihantini, Ratna. (2009). Analisis pengaruh Inflasi, Nilai Tukar, ROA, DER, dan CR terhadap Return Saham (Sutudi Kasus Saham Industri dan real Estate and Property yang Terdaftar di BEI Periode 2003-2006). Tesis yang diterbitkan. Semarang: Universitas Diponegoro.

Putri, Ainun Astori. 2014. Pengaruh Kinerja Keuangan Terhadap Return Saham Pada Sektor Pertabangan, Properti, Real estate, Dan Konstruksi Bangunan Yang Terdaftar Di Bursa Efek Indonesia Tahun 2008-2012. Skripsi Universitas Sebelas Maret. Surakarta.

Putri, Ainun Astori. 2014. Pengaruh Kinerja Keuangan Terhadap Return Saham Pada Sektor Pertabangan, Properti, Real estate, Dan Konstruksi Bangunan Yang Terdaftar Di Bursa Efek Indonesia Tahun 2008-2012. Skripsi Universitas Sebelas Maret. Surakarta.

Rachmawan, Abid. 2011. Pengaruh Rasio Keuangan Dan Variabel Makro Terhadap Return Yang Diterima Oleh Pemegang Saham Pada Perusahaan Perdagangan Di Bursa Efek Syariah. Skripsi UIN Sunan Kalijaga. Yogyakarta.

Rachmawan, Abid. 2011. Pengaruh Rasio Keuangan Dan Variabel Makro Terhadap Return Yang Diterima Oleh Pemegang Saham Pada Perusahaan Perdagangan Di Bursa Efek Syariah. Skripsi UIN Sunan Kalijaga. Yogyakarta.

Salvatore, Dominick, 2005, Ekonomi Manajerial, Buku 2. Salemba Empat: Jakarta.

Salvatore, Dominick, 2005, Ekonomi Manajerial, Buku 2. Salemba Empat: Jakarta.

Samsul, Mohammad. 2006. Pasar Modal dan Manajemen Portofolio. Erlangga, Jakarta

Samsul, Mohammad. 2006. Pasar Modal dan Manajemen Portofolio. Erlangga, Jakarta

Sartono, Agus. 2001. Manajemen Keuangan "Teori dan Aplikasi", Edisi Keempat. BPFE, Yogyakarta.

Sartono, Agus. 2001. Manajemen Keuangan "Teori dan Aplikasi", Edisi Keempat. BPFE, Yogyakarta.

Savitri, Dyah Ayu. 2010. Analisis ROA, NPM, EPS, Dan PER Terhadap Return Saham (Studi Kasus Pada Perusahaan Manufaktur Sektor Food and Beverage
Periode 2007-2010). Skripsi Universitas Diponegoro. Semarang.

Savitri, Dyah Ayu. 2010. Analisis ROA, NPM, EPS, Dan PER Terhadap Return Saham (Studi Kasus Pada Perusahaan Manufaktur Sektor Food and Beverage Periode 2007-2010). Skripsi Universitas Diponegoro. Semarang.

Subalno. (2009). Analisis Pengaruh Faktor Fundamental dan Kondisi Ekonomi terhadap Return Saham (Studi Kasus Pada Perusahaan Otomotif dan Komponen Yang Listed di Bursa Efek Indonesia Periode 2003-2007). ORBITH Vol. 6, No. 1. Semarang: Universitas Diponegoro.

Subalno. (2009). Analisis Pengaruh Faktor Fundamental dan Kondisi Ekonomi terhadap Return Saham (Studi Kasus Pada Perusahaan Otomotif dan Komponen Yang Listed di Bursa Efek Indonesia Periode 2003-2007). ORBITH Vol. 6, No. 1. Semarang: Universitas Diponegoro.

Suci, K. S. 2012. Pengaruh Inflasi, Suku Bunga dan Kurs dan Pertumbuhan PDB Terhadap Indeks Harga Saham Gabungan. Jurnal Economica. Vol 8(1). 53-64.

Suci, K. S. 2012. Pengaruh Inflasi, Suku Bunga dan Kurs dan Pertumbuhan PDB Terhadap Indeks Harga Saham Gabungan. Jurnal Economica. Vol 8(1). 53-64.

Sugiyono. 2010. Metode penelitian dan Bisnis. Alfabeta. Bandung.

Sugiyono. 2010. Metode penelitian dan Bisnis. Alfabeta. Bandung.

Sujarweni, V. Wiratna. 2015. SPSS Untuk Penelitian. Pusstaka Baru Press. Yogyakarta.

Sujarweni, V. Wiratna. 2015. SPSS Untuk Penelitian. Pusstaka Baru Press. Yogyakarta.

Sukirno, Sadono, Makro Ekonomi Teori Pengantar, Edisi III. PT Raja Grafindo Persada. Jakarta

Sukirno, Sadono, Makro Ekonomi Teori Pengantar, Edisi III. PT Raja Grafindo Persada. Jakarta

Supadi, Dwi Budi Prasetyo dan M. Nuryanto Amin. (2012). Pengaruh Faktor Fundamental Dan Risiko Sistematis Terhadap Return Saham Syariah. Media 
Riset Akuntansi, Auditing \& Informasi. 12 (1)

Supadi, Dwi Budi Prasetyo dan M. Nuryanto Amin. (2012). Pengaruh Faktor Fundamental Dan Risiko Sistematis Terhadap Return Saham Syariah. Media Riset Akuntansi, Auditing \& Informasi. $12(1)$

Susilawati \& Turyanto. 2011. Reaksi Signal Rasio Profitabilitas dan Rasio Solvabilitas Terhadap Return Perusahaan, Jurnal Dinamika Keuangan dan Perbankan, Vol.3 (1): 17-37.

Susilawati \& Turyanto. 2011. Reaksi Signal Rasio Profitabilitas dan Rasio Solvabilitas Terhadap Return Perusahaan, Jurnal Dinamika Keuangan dan Perbankan, Vol.3 (1): 17-37.

Tandelilin, Eduardus, 2001, Analisis Investasi dan Manajemen Portofolio, Edisi Pertama, BPFE: Yogyakarta.

Tandelilin, Eduardus, 2001, Analisis Investasi dan Manajemen Portofolio, Edisi Pertama, BPFE: Yogyakarta.

Van Horne, James, Jonh M Wachowicz, Jr. (1997). Prinsip-prinsip Manajemen Keuangan. Jakarta: Salemba Empat.

Van Horne, James, Jonh M Wachowicz, Jr. (1997). Prinsip-prinsip Manajemen Keuangan. Jakarta: Salemba Empat.

Wahyu, Dwi P. 2010. Analisis Pengaruh Faktor Fundamental Ekonomi Makro dan Harga Minyak Terhadap Saham LQ45 dalam Jangka Pendek dan Jangka Panjang. Journal Of Indonesian Applied Economics. Vol 4 (1): 11-25.

Wahyu, Dwi P. 2010. Analisis Pengaruh Faktor Fundamental Ekonomi Makro dan Harga Minyak Terhadap Saham LQ45 dalam Jangka Pendek dan Jangka Panjang. Journal Of Indonesian Applied Economics. Vol 4 (1): 11-25.

Wahyudi, Sugeng. (2003). "Pengaruh Rasio Harga Nilai Buku dan Rasio Hutang Modal Sendiri terhadap Return". Media Ekonomi dan Bisnis, Vol. XV, No. 2.

Wahyudi, Sugeng. (2003). "Pengaruh Rasio Harga Nilai Buku dan Rasio Hutang Modal Sendiri terhadap Return”. Media Ekonomi dan Bisnis, Vol. XV, No. 2.

Weston, J.F. dan Copeland, T.E., 1995, Manajemen Keuangan, Jilid 1, Binarupa Aksara: Jakarta.
Weston, J.F. dan Copeland, T.E., 1995, Manajemen Keuangan, Jilid 1, Binarupa Aksara: Jakarta.

Widodo, Saniman. 2007. Analisis Pengaruh Rasio AKtifitas, Rasio Profitabilitas dan Rasio Pasar Terhadap Return Saham Syariah dalam Kelompok Jakarta Islamic Index (JII), Tesis tidak diterbitkan, Pascasarjana Universitas Diponegoro, Semarang.

Widodo, Saniman. 2007. Analisis Pengaruh Rasio AKtifitas, Rasio Profitabilitas dan Rasio Pasar Terhadap Return Saham Syariah dalam Kelompok Jakarta Islamic Index (JII), Tesis tidak diterbitkan, Pascasarjana Universitas Diponegoro, Semarang.

www.bi.go.id.

www.bi.go.id.

www.bps.go.id

www.bps.go.id.

www.sahamok.com.

www.sahamok.com. Ang, Robert, 1997, Buku Pintar: Pasar Modal Indonesia. Mediasoft Indonesia, Jakarta. 